\title{
PENGGUNAAN METODE INDEX CARD MATCH TERHADAP PENGUASAAN KOSAKATA BAHASA ARAB
}

\author{
Nurlaila, M. Pd.
}

(ipanurlaila@gmail.com)

\section{(Dosen Fakultas Tarbiyah IAI Muhammadiyah Bima)}

\begin{abstract}
الملكخص
صارت اللغة العربية لغة رسمية في أمم المتحدة منذ السنة 1973م ولذلك كانت اللغة العربية لغة التفاهم بين الشعوب العربية فى العالم. وإذا نظرنا إلى انتشار اللغة العربية فى بلادنا كانت اللغة العربية مستخدمة لتعليم العلوم الدينية الإسلامية كالمعاهد والمدارس فى تدريس الكتب السلافية. ولذلك كانت الطريقة البطاقة لها مكانت مهمة. ولنيل مكافأة الطلاب فى تعليم المفردات لأن مكافأة الطلاب متفرقة، منهم يقدرون في اللغة العربية ويفهمون المفردات ومنهم لايستطيعون. ولذلك يجب على المدرس أن يكون ايجابيا فى تعليم العربية كما فى التختيط. وبجانب ذالك لابد على المدرس ان يأخد قرارا جيدا حينما يعرف المدرس الطلاب لم يستطيعوا فى فهم الدرس أولم يصلوا الى غرض التعليم. إن المبادئ الأسـاسى فى التعليم ليس إعطائ الأخبار الإجتماعية فحسب بدون العاملى، ولكن لا بد للمدرس أن يعلم عامليا الى الطلاب.
\end{abstract}

كلمات المفتاح : الطريقة، المفردات، اللغة العربية.

Bahasa Arab memiliki peran yang sangat penting sebagai bahasa semua suku di Arab dan merupakan bahasa yang digunakan secara resmi dalam Persyarikatan BangsaBangsa ( PBB) pada tahun 1973. bahasa Arab juga sebagai bahasa untuk memahami semua hal yang berkaitan dengan Islam. Serta dipelajari di Indonesia, tidak hanya pada pondok- pondok pesantren, melainkan juga pada sekolah formal baik negeri maupun swasta. Kemampuan siswa dalam memahami bahasa Arab dalam hal ini mufradat berbeda-beda, diantara mereka sudah memahaminya, namun sebagian yang lain belum memahaminya. Untuk mendapatkan kemampuan siswa dalam penguasaan mufradat, maka dibutuhkan metode pembelajaran yang sesuai diantaranya adalah metode Index 
Card Match. Metode ini mampu menjadikan pembelajaran menjadi aktif dan menyenangkan. Selain itu guru juga harus membuat perencanaan pembelajaran yang baik dan peran juga aturan yang baik ketika mengetahui bahwa murid belum memahami pelajaran dan belum mencapai tujuan pembelajaran, karna prinsip pembelajaran tidak hanya menyampaikan informasi tetapi harus menjadikan murid tersebut aktif dalam pembelajaran.

\section{Kata Kunci: Metode Index Card Match, Kosakata, Bahasa Arab}

\section{A. PENDAHULUAN}

Pembelajaran merupakan salah satu unsur penting dalam suatu pendidkan, karena pembelajaran ibarat jantung dari proses pendidikan, pembelajaran yang baik cendrung menghasilkan hasil belajar yang baik pula demikian sebaliknya, pembelajaran dapat diartikan sebagai interaksi bolak- balik di antara dua pihak yang saling membutuhkan, yaitu pendidikan dan peseta didik.

Menurut Fatur Rohman, pembelajaran merupakan sebuah proses yang di dalamnya mencakup pengertian seorang guru mengajarkan pengetahuan kepada anak didik dan usaha anak didk untuk mempelajari suatu pengetahuan. ${ }^{1}$ Sedangkan menurut Abdul Majid, pembelajaran (instruction) bermakna sebagai "upaya untuk membelajarkan seseorang atau kelompok orang melalui berbagai upaya (effort) dan berbagai strategi, metode dan pendekatan ke arah pencapaian tujuan yang telah direncanakan."

Dari pengertian di atas dapat dipahami bahwa pembelajaran adalah kegiatan yang terencana yang mengkondisikan seseorang dapat belajar dengan baik agar sesuai dengan tujuan yang ingin dicapai. Dalam pembelajaran sudah tentu akan terjadi proses belajar, maka dari itu pula terjadi proses mengajar. Hal ini kiranya mudah dipahami karena jika ada yang belajar sudah tentu ada yang mengajarnya, dan begitu juga sebaliknya jika ada yang mengajar tentu ada yang belajar. Setiap pembelajaran tidak akan lepas dari pendekatan, metode, media maupun strategi yang akan digunakan agar tujuan dari pembelajaran dapat tercapai secara cepat, efektif, dan efisien.

\footnotetext{
${ }^{1}$ Fatur Rohman, Metodologi Pembelajaran Bahasa Arab, (Malang: Madani, 2015), 23.

${ }^{2}$ Abdul Majid, Strategi Pembelajaran, (Bandung: Remaja Rosdakarya, 2013), 4.
} 
Secara umum strategi sering diungkapkan sebagai suatu teknik yang digunakan untuk mencapai suatu tujuan. Sedangkan strategi pembelajaran adalah suatu perangkat materi dan prosedur pembelajaran yang digunakan secara bersama- sama untuk menimbulkan hasil belajar pada peserta didik yang lebih baik. Sedangkn menurut Abdul Hamid dan Mustofa yang menyebutkan bahwa strategi pembelajaran merupakan rencana, aturan- aturan, langkah- langkah serta sarana yang prakteknya akan diperankan dan dilalui dari pembukaan sampai penutupan dalam proses pembelajaran di dalam kelas guna merealisasikan tujuan. ${ }^{3}$ Dari pengertian diatas dapat kita ketahui bahwa strategi pada intinya adalah suatu rencana yang di rancang kemudian dilakukan untuk mencapai tujuan yang ingin dicapai dalam pembelajaran Bahasa Arab.

Menurut Asrori hakikat belajar bahasa Arab adalah untuk keperluan komunikasi sosial, sedangkan pembelajaran bahasa Arab pada hakikatnya adalah pengembangan kemahiran berkomunikasi sosial dengan menggunakan bahasa Arab. Akan tetapi pembelajaran bahasa Arab dianggap sulit oleh sebagian besar peserta didik, meskipun sebenarnya bahasa Arab itu mudah. Maka dari itu dibutuhkan strategi pembelajaran yang sesuai agar peserta didik tidak merasa kesulitan. $^{4}$

\section{B. KOSAKATA BAHASA ARAB}

Pembelajaran bahasa Arab yang ideal adalah pembelajaran yang memungkinkan peserta didik menguasai empat keterampilan berbahasa (maharatul al-istima, al-kalam, al-qiro'ah dan al-kitabah) secara proporsional. Hal ini disebabkan bahasa Arab bukan hanya sekedar berfungsi pasif, yaitu sebagai media untuk memahami (al fahm) apa yang dapat didengar, berita, teks,

\footnotetext{
${ }^{3}$ Bisri Mustofa dan Abdul Hamid, Metode dan Strategi Pembelajaran Bahasa Arab, (Malang: UIN Maliki Press, 2012), 67

${ }^{4}$ Khansa Onita Hasna, "Strategi Pembelajaran Bahasa Arab”(Malang: UNIVERSITAS NEGERI MALANG Mahasiswa Magister Keguruan Bahasa Arab, 2016) ISSN: 2540 - 9417, 1
} 
bacaan dan wacana, melainkan juga berfungsi aktif, yaitu memahamkan (alifham) orang lain memalui komunikasi lisan dan tulisan. ${ }^{5}$

\section{Makna dan Fungsi Kosakata Bahasa Arab (Mufrodat)}

Kosakata merupakan salah satu unsur terpenting dalam bahasa termaksud bahasa Arab di samping kaidah tata bahasa/ilmu nahwu (sintaksis), ilmu sharaf (marfologi), dan ilmu aswat (fonetik). Setiap bahasa termaksud bahasa Arab memiliki kosakata yang mempunyai fungsi, peran, serta pengaruh yang besar dalam pembelajaran di dalamnya, terlebih lagi mempelajari bahasa Arab bagi pelajar Indonesia berarti mempelajari bahasa asing/bahasa kedua oleh karenanya memperluas kosakata merupakan prasyarat dan tuntutan yang mendasari seseorang menguasai bahasa kedua tersebut.

Kosakata merupakan salah satu unsur terpenting yang harus dimiliki oleh pembelajar bahasa termasuk bahasa Arab. Perbendaharaan kosakata bahasa Arab yang memadai dapat menunjang seseorang dalam berkomunikasi dan menulis dengan bahasa tersebut. Dengan demikian, dapat dikatakan bahwa berbicara dan menulis yang merupakan kemahiran berbahasa harus didukung oleh pengetahuan dan penguasaan kosakata yang kaya, produktif dan actual. Dengan penguasaan kosakata bahasa yang memadai peserta didik akan mempunyai bekal ilmu pengetahuan tambahan yang berguna untuk jenjang pendidikan yang lebih tinggi.

Kosakata sebagai khazanah kata akan mempunyai fungsi bilamana mempunyai makna. Makna sebuah kata dapat dibedakan menjadi dua yaitu makna denotatif (المعنى الإضافى) dan makna konotatif (المعنى الإضافى). Makna denotatif (أصلى) adalah makna yang terdapat dalam kamus. Makna denotatif terdiri dari makna hakiki dan makna kiasan. Misalnya kata al-umm (الأم), makna hakikinya adalah" ibu yang melahirkan", sedangkan makna kiasan terlihat bila kata al-umm (الأم) digunakan dalam kata umm al-kitab (أم الكتاب). Makna denotatif juga bisa dibedakan antara makna asal dan makna istilah.

\footnotetext{
${ }^{5}$ Insania, “Pendekatan dan Strategi Pembelajaran Bahasa Arab”, Jurnal pemikiran Al ternatif kependidikan, volume 11 No 2 (Januari - April 2006), 1.
} 
Kata al-hatif makna asalnya adalah "orang yang berbisik", sedangkan makna istilahnya adalah "telepon". Makna konotatif adalah makna tambahan yang terkandung di dalamnya nuansa atau kesan khusus sebagai sebab akibat dari pengalaman para pemakai bahasa. Contohnya kata al-umm makna konotatifnya adalah kasih sayang dan perlindungan.

Ditinjau dari segi fungsinya, kosakata (al-mufradât) terbagi menjadi dua yaitu:

a. Al-Mufradât Mu’jamiyah (المفردات المعجمية) Yaitu kosakata yang بيت, قلم, سيّارة mempunyai makna dalam kamus, seperti

b. Al-Mufradât Wadzifiyah (المفردات الوظفية) Yaitu kosakata yang mengemban fungsi sintaksis tertentu, seperti huruf jar, nawashib, jawazim, asma almaushul, dhama'ir, dan lain-lain.

Dari dua macam kosakata tersebut, perlu dicatat bahwa diantara $\mathrm{Al}$ Mufradât Mu’jamiyah (المفردات المعجمية) terdapat beberapa hal yang perlu diketahui, yaitu:

a) Terdapat beberapa kata yang memiliki kemiripan makna seperti kata, نظر شاهد yang memiliki makna "melihat, memandang, memperhatikan, menyaksikan".

b)Terdapat beberapa kata yang memiliki makna denotatif yang sama, tetapi mengadung makna konotatif yang berbeda dalam konteks pemakaiannya, seperti kata توفي dang dalam diartikan dalam bahasa Indonesia dengan "mati, meninggal, wafat, tewas atau mampus.

c)Kata yang memiliki beberapa makna yang berbeda (Musytarak), seperti kata فصل yang bisa berarti "kelas", "musim" dan "bab". 6

\section{Tujuan pembelajaran Mufradat (kosakata)}

Tujuan umum pembelajaran kosakata (mufradat) bahasa Arab adalah sebagai berikut:

a. Memperkenalkan kosakata baru kepada siswa atau mahasiswa, baik melalui bahan bacaan maupun fahm al-musna'.

\footnotetext{
${ }^{6}$ Syamsuddin Asyrofi, Metodologi Pengajaran Bahasa Arab: Konsep dan Implementasinya, (Yogyakarta: Penerbit Ombak, 2016), 129.
} 
b. Melatih siswa atau mahasiswa untuk dapat melafalkan kosakata itu dengan baik dan benar karena pelafalan yang baik dan benar dapat mengantarkan kepada kemahiran berbicara dan membaca secara baik dan benar pula.

c. Memahami makna kosakata, baik secara denotasi atau leksikal (berdiri sendiri) maupun ketika digunakan dalam konteks kalimat tertentu (makna konotatif dan gramatikal).

d. Mampu mengapresiasi dan memfungsikan mufradat itu dalam berekspresi lisan (berbicara) maupun tulisan (mengarang) sesuai dengan konteksnya yang benar. ${ }^{7}$

Dalam pembelajaran kosakata, seorang guru harus menyiapkan kosakata yang tepat bagi siswa - siswanya. Oleh karena itu, guru harus berpegang pada prinsip - prinsip dalam pemilihan kosakata yang akan diajarkan kepada para siswa adalah sebagai berikut:

a) Frequency artinya memilih kosakata yang sering digunakan. Contohnya : kata نَ نَرْ harus lebih diutamakan dari pada kata نُرْعَة hama - sama berarti sungai, karena yang kedua jarang digunakan. Bahkan hanya kata نَ نَ نَرْ digunakan dalam Al-qur'an.

b) Range artinya memilih kosakata yang banyak digunakan di negara - negara Arab, yang tidak hanya banyak digunakan di sebagian negara Arab. Standar dan acuannya adalah Mu'jam al-Raashid al-Lughawy li al-tifl al-'Araby yang disusun oleh ISESCO.

c) Avaibility artinya, kata yang dikuasai oleh seseorang ketika hendak digunakan lebih diutamakan dari pada yang tidak diketahuinya. Misalnya kata جَلَسن hampir pasti lebih dahulu di ketahui dan dikuasai peserta didik dari pada kata قَعَد

d)Familiarty artinya, memilih kata- kata yang familiar dan terkenal serta meninggalkan kata- kata yang jarang terdengar penggunaanya. Seperti, kata

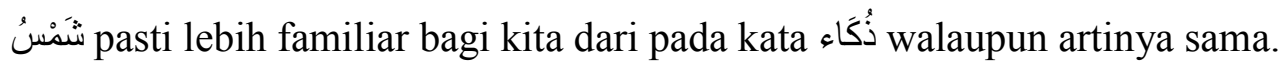

\footnotetext{
${ }^{7}$ Mu'at, "Strategi Pembelajran Kosakata (Mufradat) Bahasa Arab”, Al-Ta'dib,No.1, Volume 3 (Juli 2013), 84 .
} 
e) Coverege artinya, memilih kata- kata yang dapat digunakan dalam berbagai

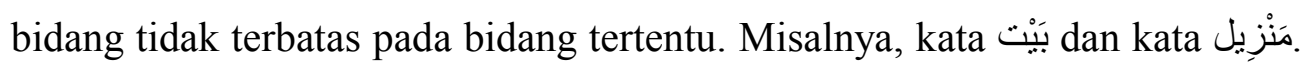
Kata بَيْتِ jelas lebih komprehensif dari pada kata مَنْزِيل pertama (بَيَتِ القَصِيد, بيت :mencangkup berbagai bidang seperti ungkapan المَال, بيت العَنْكَبُوت

f) Ahammiyah artinya memilih kata- kata yang sering dibutuhkan penggunaannya oleh siswa dari pada kata- kata yang terkadang tidak dibutuhkan atau jarang dibutuhkan. ${ }^{8}$

\section{Teknik- Teknik Pembelajaran Mufradat}

Dalam mengajarkan kosakata pada siswa, ada beberapa langkah langkah yang harus diperhatikan agar pembelajaran unsur tersebut berhasil antara lain sebagai berikut:

a. Mendengarkan kata. Berikan kesempatan kepada siswa untuk mendengarkan kata yang diucap guru.

b. Mengucapkan kata. Setelah mendengar ucapan guru, siswa diberi kesempatan untuk mengucapkan kata yang telah di dengarnya.

c. Mendapatkan makna kata. Hindari penerjemahan secara langsung dalam bahasa Indonesia. Ada beberapa teknik yang bisa digunakan guru untuk menghindari terjemahan, antara lain dengan pemberian konteks, definisi sederhana dalam bahasa Arab, menunjukan sinonim (padanan kata) atau antonim (lawan kata) dalam bahasa Arab, pemakaian gambar dan lain-lain.

d. Menulis kata. Akan sangat membantu penguasaan kosakata, jika siswa diminta menuliskan kembali kosakata yang baru dipelajarinya.

e. Membuat kalimat. Tahap terkahir dari kegiatan pengajaran kosakata adalah menggunakan kata- kata baru dalam sebuah kalimat yang sempurna, baik secara lisan maupun tulisan. ${ }^{9}$

Teknik atau langkah-langkah pembelajaran kosakata diatas yang dapat dijadikan acuan para pengajar bahasa asing khususnya bahasa Arab, walaupun

${ }^{8}$ Baiq Tuhfatul Unsi, “ Media Gambar dalam Pembelajarn Kosakata”, Tafaquh, No. 1, Volume 2 (Juni 2014), 34.

${ }^{9}$ Ibid., 130. 
tidak semua kosakata baru harus dikenalkan dengan teknik dan langkah langkah tersebut.

Menurut Ahmad Hamid dalam Abdul Hamid, ada beberapa cara yang dapat dilakukan guru untuk menjelaskan makna kosakata, diantaranya adalah :

a. Dengan cara menunjukan langsung pada benda (kosakata) yang diajarkan.

b. Dengan cara menghadirkan miniature dari benda (kosakata) yang diajarkan.

c. Dengan cara memberikan gambar dari kosakata yang ingin diajarkan.

d. Dengan cara memperagakan kosakata yang ingin disampaikan. Contoh: seorang guru ingin menyampaikan kosakata (khususnya yang terkait dengan kata kerja) maka guru bisa melakukannya dengan cara memperagakan tersebut tanpa harus menerjemahkan ke dalam bahasa ibu, seperti kosakata يَمْنِى guru cukup memperagakan dengan berjalan didepan kelas.

e. Dengan cara memasukkan kosakata yang diajarkan kedalam kalimat.

f. Dengan cara memberikan padanan kata (أنَّرَادف). Contoh :ketika guru ingin mengajarkan kosakata فَصْنّ maka ia harus memberikan padanannya صَف

g. Dengan cara memberikan lawan kata المُضضَاف.

h. Dengan cara memberikan definisi dari kosakata yang diberikan. Contoh : guru memberikan kosakata المَسْجِدُ maka dia cukup memberikan definisinya yaitu مَكَانُ للِصَّلَاةِ وَالإعْنِكَافِ.

i. Apabila dari langkah-langkah tersebut di atas masih belum dipahami oleh siswa, atau ada kosakata yang tidak bisa diungkapkan dengan delapan langkah yang ada maka mengartikan kosakata kedalam bahasa ibu sebagai langkah yang terakhir. ${ }^{10}$

Dalam mengajarkan kosakata (mufradât) bahasa Arab ada beberapa hal yang harus diperhatikan, antara lain sebagai berikut:

a. Pengajaran mufradat tidak berdiri sendiri, melainkan terkait dengan pengajaran muthala'ah, istima, insya', dan muhadatsah.

\footnotetext{
${ }^{10}$ Abd Wahab Rosyidi \& Mamlu'atul Ni'mah, MemahamiKonsep Dasar Pembelajaran Bahasa Arab, (Malang; UIN- Maliki Press, 2012), 123-125.
} 
b. Suatu kata dapat memiliki beberapa makna. Oleh karena itu, untuk siswa pemula, sebaiknya guru hanya mengajarkan makna yang sesuai dengan konteksnya saja.

c. Banyak kosakata yang tidak bisa dipahami, kecuali sesuai dengan konteksnya sehingga harus diajarkan sesuai konteksnya agar tidak mengacaukan pemahaman siswa.

d. Dalam mengajarkan kosakata, hindari sebisa mungkin penerjemahan secara langsung kedalam bahasa Indonesia, kecuali sangat terpaksa.

e. Ajarkan kosakata sesuai dengan tingkat kesukarannya secara bertahap. ${ }^{11}$

\section{METODE INDEX CARD MATCH}

\section{Makna dan Fungsi Metode Index Card Match}

Metode mengajar ialah cara yang digunakan oleh guru untuk menyampaikn pelajaran kepada pelajar. Karna penyampaian itu berlangsung dalam interaksi edukatif, metode mengajar dapat diartikan sebagai cara yang dipergunakan oleh guru dalam mengadakan hubungan dengan pelajar pada saat berlangsungnya pengajaran. Dengan demikian, metode mengajar merupakan alat untuk menciptakan proses belajar mengajar. ${ }^{12}$

Menurut Silberman, Index Card Match (mencari pasangan kartu) merupakan cara yang menyenangkan dan aktif untuk mengkaji materi pembelajaran. Dengan metode index card match siswa dapat aktif dalam proses pembelajaran, siswa akan belajar menyampaikan sesuatu pemahaman pada teman serta dapat menjadi pendengar yang baik saat teman lain menyampaikan suatu pemahaman, sehingga siswa memiliki antusias dalam proses pembelajaran untuk berlomba- lomba mencari pasangan dari setiap kartu yang dia miliki baik kartu yang berisi pertanyaan maupun kartu yang berisi jawaban. ${ }^{13}$

\footnotetext{
${ }^{11}$ Syamsuddin Asyrofi, Metodologi Pengajaran .............., 129-130.

${ }^{12}$ Departemen Ri, Metedologi Pendidikan agaman Islam, (Semarang: Rasail Media Group, 2008), 8.

${ }^{13}$ Suwarni Al Suawrtiani, "Metode Index Card Match untuk Meningkatkan Hasil Belajar Mapel IPS Kelas VI SD". 2.
} 


\section{Kelebihan dan Kekurangan Metode Index Card Match}

Adapun kelebihan dari metode Index Card Match adalah:

a. Menumbuhkan kegembiraan dalam kegiatan belajar mengajar.

b. Materi pelajaran yang disampaikan lebih menarik perhatian siswa.

c. Mampu mnciptakan suasana belajar yang aktif dan menyenangkan.

d. Mampu meningkatkan hasil belajar siswa mencapai taraf ketuntasan belajar.

e. Penilaian dilakukan bersama pengamat dan pemain.

\section{Sedangkan kelemahan dari Metode Index Card Match:}

a) Membutuhkan waktu yang lama bagi siswa untuk menyelesaikan tugas.

b) Guru harus meluangkan waktu yang lebih lama untuk membuat persiapan.

c) Guru harus memiliki jiwa demokratis dan keterampilan yang memadai dalam hal pengelolaan kelas.

d) Menuntut sifat tertentu dari siswa atau kecenderungan untuk bekerja sama dalam menyelesaikan masalah.

e) Suasana kelas menjadi lebih gaduh sehingga dapat mengganggu kelas lain.

\section{Ciri-ciri Metode Index Card Match}

Index card match merupakan model yang digunakan pembelajaran aktif dengan jalan meninjau ulang materi dengan ciri-ciri:

a. Metode ini menggunakan kartu

b. Kartu dibagi menjadi dua yang berisi satu pertanyaan dan satu untuk jawaban

c. Metode ini dilakukan secara berpasangan

d. Setiap pasangan membacakan pertanyaan dan jawaban.

\section{Prinsip-prinsip Metode Index Card Match adalah:}

Beberapa prinsip yang harus diperhatikan ketika guru menerapkan Index Card Match adala sebagai berikut:

a. Memahami sifat peserta didik

Pada dasarnya peserta didik memiliki sifat rasa ingin tahu atau berimajinasi. 
Kedua sifat ini merupakan dasar bagi berkembangnya sikap/berpikir krisis dan kreatif. Untuk itu kegiatan pembelajaran harus dirancang menjadi lahan yang subur bagi berkembangan kedua sifat tersebut.

b. Mengenal peserta didik secara perorangan

Peserta didik berasal dari latar belakang dan kemampuan yang berbeda. Perbedaan individu harus diperhatikan dan garis tercermin dalam pembelajaran. Semua peserta didik dalam kelas tidak harus selalu mengerjakan kegiatan yang sama, melainkan berbeda dengan kecepatan belajrnya. Peserta didik yang memiliki kemampuan lebih dapat dimanfaatkan untuk membantu temannya yang lemah (tutor sebaya)

c. Memanfaatkan perilaku peserta didik dalam berorganisasi belajar.

Peserta didik selain bermain secara berpasangan atau kelompok. Perilaku yang demikian dapat dimanfaatkan oleh guru dalam pengorganisasian kelas. Dengan berkelompok akan mempermudah mereka untuk berinteraksi atau bertukar pikiran.

d. Mengembangkan kemampuan berpikir kritis dan kreatif serta mampu memecahkan masalah

Pada dasarnya hidup adalah memecahkan masalah, untuk itu peserta didik perlu dibekali kemampuan berpikir kritis dan kreatif untuk menganalisi masalah, dan kreatif untuk melahirkan alternatif pemecahan masalah, dan kreatif untuk melahirkan alternatif pemecahan masalah. Jenis pemikiran tersebut sudah ada sejak lahir, guru diharapkan dapat mengembangkannya.

e. Menciptakan ruangan kelas sebagai lingkungan belajar yang menarik Ruangan kelas yang menarik sangat disarankan dalam Index CardMatch. Hasil pekerjaan peserta didik sebiknya dipajang di dalam kelas, karena dapat memotivasi peserta didik untuk bekerja labih baik dan menimbulkan inspirasi bagai peserta didik yang lain. Selain itu pajangan dapat juga dijadikan bahan ketika membahas materi pelajaran yang lain.

f. Memanfaatkan ruangan kelas sebagai lingkungan belajar yang menarik. Ruangan kelas yang menarik sangat disarankan dalam kelas, karena dapat memotivasi peserta didik untuk bekerja lebih dan menimbulkan inspirasi 
bagi peserta didik yang lain.

g. Memanfaatkan lingkungan sebagai lingkungan belajar

Lingkungan (fisik, sosial, budaya) merupakan sumber yang sangat kaya untuk bahan belajar peserta didik. Lingkungan dapat berfungsi sebagai media belajar serta objek belajar peserta didik.

h. Memberikan umpan balik yang baik untuk meningkatkan kegiatan

i. Pemberian umpan balik dari guru kepada peserta didik merupakan suatu interaksi antar guru dengan peserta didik. Umpan balik hendaknya lebih mengungkapkan kekuatan dan kelebihan peserta didik dari pada kelemahannya. Umpan balik juga harus dilakukan secara santun dan elegan sehingga tidak meremehkan dan menurunkan motivasi.

j. Membedakan antara aktif-fisik dengan aktif mental.

k. Dalam pembelajaran index card match, aktif secara mental lebih diinginkan dari pada aktif fisik. Karena itu, aktifitas sering bertanya, mempertanyakan gagasan orang lain, mengemukakan gagasan merupakan tanda-tanda aktif mental.

\section{Penggunaan Index Card Match Dalam Penguasaan Kosakata Bahasa Arab}

Adapun langkah- langkah dari penggunaan Index Card Match adalah:

a. Buatlah potongan- potongan kertas sebanyak jumlah siswa yang ada didalam kelas.

b. Bagilah kertas- kertas tersebut menjadi dua bagian yang sama.

c. Pada separuh bagian, tulis pertanyaan tentang materi yang akan dibelajarkan. Setiap kertas berisi satu pertanyaan.

d. Pada separuh kertas yang lain, tulis jawaban dari pertanyaan-pertanyaan yang telah dibuat.

e. Kocoklah semua kertas sehingga akan tercampur antara soal dan jawaban.

f. Setiap siswa diberi satu kertas. Jelaskan bahwa ini adalah aktifitas yang dilakukan berpasangan. Separuh siswa akan mendapatkan soal dan separuhnya lagi akan mendapatkan jawaban . 
g. Mintalah kepada siswa untuk menemukan pasangan mereka. Jika ada yang sudah menemukan pasangan, mintalah kepada mereka untuk duduk berdekatan.

h. Setelah semua siswa menemukan pasangan dan duduk berdekatan, mintalah kepada setiap pasangan secara secara bergantian untuk membacakan soal yang diperoleh dengan keras kepada teman-temannya yang lain. Selanjutnya soal tersebut dijawab oleh pasangannya.

i. Akhiri proses ini dengan membuat klarifikasi dan kesimpulan. ${ }^{14}$ :

\section{KESIMPULAN}

Metode Index Card Match yaitu suatu pembelajaran aktif yang dikenalkan oleh Meil Sibermen yang bertujan agar pembelajaran lebih aktif terutama bagi peserta didik. Metode ini juga termasuk dari salah satu pembelajaran yang cukup menyenangkan yang digunakan untuk mengulang materi yang telah disampaikan sebelumnya. Namun demikian materi baru pun tetap bisa diajarin dengan metode ini. dengan catatan siswa diberi tugas untuk mempelajari topik yang akan diajarkan terlebih dahulu. Manfaat yang bisa didapat ketika menerapkan metode pembelajaran dengan menggunakan metode Index Card Match adalah guru dapat menciptakan suasana belajar yang mendorong anak-anak untuk saling membutuhkan, inilah yang dimaksud positive interdepence atau saling ketergantungan positif.

Pembelajaran bahasa Arab dalam hal ini pembelajaran mufradat bisa dilakukan dengan berbagai metode pembelajaran. Metode pembelajaran merupakan segala sesuatu yang dapat menyalurkan pesan, merangsang pikiran, dan kemauan peserta didik sehingga dapat terciptanya proses belajar pada diri siswa. Secara umum manfaat metode pembelajaran adalah untuk memperlancar interaksi guru dan siswa sehingga kegiatan pembelajaran lebih efektif dan efisien, proses pembelajarn menjadi lebih jelas dan menarik. Salah satu metode

\footnotetext{
${ }^{14}$ Agus Suparjino, Cooperative Learning “Teori dan Aplikasi”(Edisi Revisi), cet.XIV(Yogyakarta : Pustaka Pelajar 2005), 120.
} 
pembelajaran yang dapat guru gunakan untuk membantu siswa dalam meningkatkan penguasaan kosakata bahasa Arab (mufradât) siswa adalah dengan penggunaan Metode Index Card Match. Dengan mengunakan Metode Index Card Match siswa dapat lebih aktif lagi dalam pembelajaran, siswa didorong untuk melakukan kerja sama dalam menjawab pertanyaan dengan mencocokan kartu indeks yang ada di tanggan mereka, proses pembelajaran ini lebih menarik karena siswa mencari pasangan sambil belajar mengenai suatu konsep atau topik dalam suasana yang menyenangkan. Hal ini akan memotivasi siswa dengan semakin banyak kosakata yang mereka ketahui maka semakin besar rasa ingin tahu mereka, disamping itu media ini mudah dibuat sendiri, murah, dan efisien dalam pembuatan dan penggunaannya.

\section{DAFTAR PUSTAKA}

Abdul Hamid dan Mustofa Bisri, Metode dan Strategi Pembelajaran Bahasa Arab, Malang: UIN Maliki Press, 2012.

Abdul Majid, Strategi Pembelajaran, Bandung: Remaja Rosdakarya, 2013.

Abdul Wahab Rosyidi, \& Ni'mah Mamlu'atul, Memahami Konsep Dasar Pembelajaran Bahasa Arab, Malang; UIN- Maliki Press, 2012.

Agus Suparjino, Cooperative Learning “Teori dan Aplikasi”(Edisi Revisi), cet.XIV, Yogyakarta : Pustaka Pelajar 2005.

Al-Suawrtiani, Suwarni, "Metode Index Card Match untuk Meningkatkan Hasil Belajar Mapel IPS Kelas VI SD”

Baiq Tuhfatul Unsi, "Media Gambar dalam Pembelajarn Kosakata”, Tafaquh, No. 1, Volume 2, Juni 2014.

Departemen RI, Metedologi Pendidikan agaman Islam, Semarang: Rasail Media Group, 2008.

Fathur Rohman, Metodologi Pembelajaran Bahasa Arab, Malang: Madani, 2015.

Ismail SM, Strategi Pembelajaran Agama Islam Berbasis PAIKEM, Semarang : Rasai Media Group, 2008. 
Insania, "Pendekatan dan Strategi Pembelajaran Bahasa Arab", Jurnal Pemikiran Al Ternatif kependidikan, Volume 11 No 2, Januari - April 2006.

Khansa Onita Hasna, "Strategi Pembelajaran Bahasa Arab", Malang: UNIVERSITAS NEGERI MALANG Mahasiswa Magister Keguruan Bahasa Arab, 2016) ISSN: 2540 - 9417.

Syamsuddin Asyrofi, Metodologi Pengajaran Bahasa Arab: Konsep dan Implementasinya, Yogyakarta: Penerbit Ombak, 2016.

Mu'at, "Strategi Pembelajran Kosakata (Mufrodat) Bahasa Arab",Al Ta'dib,No.1, Volume 3, Juli 2013.

Zaini, Hisyam, Strategi Pembelajaran Aktif (Edisi Revisi), Yogyakarta : CTSD UIN Suka, 2005. 